\title{
THE MEDICAL TOURIST PRODUCT OF THAILAND: KEY FACTORS AND PROMOTION ON RUSSIAN-SPEAKING MARKETS
}

\author{
Denis USHAKOV* \\ SuanSunandha Rajabhat University, College of Hospitality \\ Industry Management, Bangkok, Thailand, e-mail: denis.us@ssru.ac.th
}

\begin{abstract}
Citation: Ushakov, D. (2021). THE MEDICAL TOURIST PRODUCT OF THAILAND: KEY FACTORS AND PROMOTION ON RUSSIAN-SPEAKING MARKETS. GeoJournal of Tourism and Geosites, 37(3), 959-964. https://doi.org/10.30892/gtg.37330-732
\end{abstract}

\begin{abstract}
Based on the results of analyze the Thai national medical tourism product's positioning on Russia market to offer the principal guidelines for development the marketing strategy of Thai medical services at Russia markets. The article is based on the data of a Russian 2020 survey, at the same time, it tracks the dynamic trend of consumer preferences since 2017. Identified key principles of health tourism commercialization in Thailand under the conditions when this tourism sector needs to be reformatted due to post-Covid conditions, assessed the efficiency of Thai medical tourism promotion on Russian-speaking markets. Recommendations for the modernization of Thailand health tourism product in terms of its constituent services, marketing, infrastructure and investment support, pricing, promotion, taking into account current trends in the global and Russian tourism markets are given.
\end{abstract}

Key words: medical tourism, healthcare, medical services, insurance, Thailand, Russia

\section{INTRODUCTION}

The scope of this study is directly related to a number of problems observed at the current stage of Thailand's economic development. Overcoming these problems will contribute to not only strengthening of the country's competitiveness and its socioeconomic system, but also to provision of additional, brand new resources needed for the nation's progress.

First of all, the unevenness of Thailand regions' infrastructural development has been leading to the sectoral imbalance in the economy and it also activates the interregional exchange of the production factors (capital, resources, labor). At the same time, medical tourism clearly demonstrates the ability to quickly form powerful export-oriented clusters in the regions with slower development, thus the latter can become the centers for attracting both domestic and foreign investments, connecting the regional economic systems to the international flows of finance, tourists, innovations and various technologies. Secondly, there is clearly a need in Thailand to modernize the system of relations between the economic center and the regions. The related conceptual principles have already found their reflection in the National Strategy of Thailand for 2018-2037 (National Strategy Committee, 2017) which is focused on the growth of regional self-sufficiency, formation of strategic profit zones and regional resources being accumulated for solving the local social and economic problems. Third, diversification of Thailand's national economy overall and its inbound tourist flows' diversification in particular have been taking place recently primarily due to the growing variety of inbound tourism types. This trend has made it possible to add many new countries to the process of Thailand's inbound tourist flow generation. Table 1 and 2 clearly show which countries remain to be of strategic importance for Thailand's tourism sector.

Table 1.15 major nationalities for tourism in Thailand, as of 2019, \% (Source: www.thaiwebsites.com)

\begin{tabular}{|c|l|c|c|l|c|}
\hline & Country & $\%$ & & Country & $\%$ \\
\hline 1 & China & 58,6 & 9 & Hong Kong & 1,32 \\
\hline 2 & Russia & 5,82 & 10 & Taiwan & 1,01 \\
\hline 3 & Japan & 5,06 & 11 & France & 0,95 \\
\hline 4 & Korea, R. & 4,21 & 12 & Germany & 0,84 \\
\hline 5 & India & 3,27 & 13 & Ukraine & 0,61 \\
\hline 6 & Vietnam & 3,16 & 14 & USA & 0,5 \\
\hline 7 & UK & 1,92 & 15 & Malaysia & 0,27 \\
\hline 8 & Indonesia & 1,63 & \multicolumn{5}{|c|}{ Others } & 18 \\
\hline
\end{tabular}

Table 2. Percent changes in the country shares of visitors to Thailand between 2015 and 2019, \% (Source: www.thaiwebsites.com)

\begin{tabular}{|c|l|c|c|l|c|}
\hline & Country & $\%$ & & \multicolumn{1}{|c|}{ Country } & $\%$ \\
\hline 1 & India & 91,9 & 9 & Japan & 30,7 \\
\hline 2 & Russia & 67,8 & 10 & Hong Kong & 22,7 \\
\hline 3 & Cambodia & 56,8 & 11 & Indonesia & 22,4 \\
\hline 4 & Laos & 49,6 & 12 & Malaysia & 21,7 \\
\hline 5 & China & 38,5 & 13 & Germany & 12,7 \\
\hline 6 & Vietnam & 38,5 & 14 & France & 8,63 \\
\hline 7 & Korea & 37,5 & 15 & UK & 4,97 \\
\hline 8 & USA & 34,6 & 16 & Taiwan & 3,67 \\
\hline & & & All countries & 32,3 \\
\hline
\end{tabular}

Fourth, despite the now relatively low share of medical services in Thailand's export structure, its recreational potential as well as its ability to generate medical innovations will make it possible to effectively implement such medical innovations in almost any province of the country (Wilson, 2020). Fifth, current global socioeconomic trends associated with the ongoing scientific and technological progress, aggravation of multiple global problems of mankind (including the

\footnotetext{
* Corresponding author
} 
consequences of the coronavirus pandemic), on the one hand, also force Thailand to form additional clusters concentrating on the form of creating, among others, tourist products in the field of medical tourism. On the other hand, the current global dynamics requires even prompter implementation of the measures which would modernize the existing system of medical tourism in Thailand, associated, for example, with the inevitability of medical services digitalization, servicing of both domestic and foreign patients, changing consumer preferences and population ageing as well as formation of the concept of active longevity (Gupta, 2004). Finally, health as such is an important economic category which characterizes not only the level of material well-being of a country's population, its innovative potential, social capital, but also the quality of national labor resources along with their ability for reproduction; quality and quantity of regional demand and consumption. In other words, it is a complex combination of parameters which reflects both long-term progress and the specificity of the current stage of socioeconomic progress in any given country (Aizura, 2019). On the other hand, population of the Russian Federation (same actually applies to some other post-Soviet countries with Russian-speaking population) has a big (and growing) potential for health and medicine services consumption. A very important feature of these markets is their orientation and strong belief in foreign (first of all Western but then also Asian) medical services and their quality. This is the most specific feature of the Russian-speaking markets of the medical services, and in this they differ from the markets of Western Europe, USA or Japan (Turner, 2007). In this context, Thailand gets a solid chance and an opportunity to attract thousands of consumers from these markets, thus providing a stable national/regional income from the inflow of medical tourists. The main purpose of our research stems from the following research objectives:

-to identify the role of various specific medical services (plastic surgery, cosmetology and beauty industry) in differentiation of Thai national tourist product;

-to develop, ground and offer special medical tours to Thailand for the citizens of Russia (and other Russian-speaking countries);

-to evaluate the limits of demand for Thai national medical tourist product in Russia that would impact promotion and sales of Thai medical tours in the country;

-to develop a strategy for international marketing of Thai clinics taking into account the key specific features of medical services sales at Russian markets.

\section{MATERIALS AND METHODS}

Back in 2019, PharmaBoard placed Thailand into the top five of countries providing the best opportunities for foreign patients and investors in the medical sector (Table 3 ). Thus, medical tourism in the country has shown relatively high growth rates in recent years.

Table 3. Top-10 global destinations in medical tourism by value (in mln USD, as of 2019) (Source: https://pharmaboardroom.com)

\begin{tabular}{|c|l|c|c|l|c|}
\hline & Country & mln USD & & Country & Mln USD \\
\hline 1 & USA & 3500 & 6 & India & 450 \\
\hline 2 & Korea, S. & 655 & 7 & UK & 350 \\
\hline 3 & Turkey & 600 & 8 & Malaysia & 350 \\
\hline 4 & Thailand & 600 & 9 & Mexico & 350 \\
\hline 5 & Germany & 575 & 10 & Iran & 315 \\
\hline
\end{tabular}

According to the official data, 20\% of all foreign tourists come to Thailand with medical tourism purposes. In 2019 alone, 1.85 mln tourists visited Thailand for medical purposes, $33 \%$ of them were US citizens, $29 \%$ were representatives of China and $18 \%$ were tourists from Japan. At the same time, the interest in medical tourism in Russia is quite high, this can be somewhat explained by the unsatisfactory state of healthcare in the country. According to the research carried out by Russian sociologists, $53 \%$ of the citizens surveyed assess the healthcare status in Russia as "bad," "satisfactory" was selected by $40 \%$, and "good" -- only by 5\% of the Russian respondents (Vetitnev and Dzubina, 2018). Moreover, about 34\% of Russian doctors consider healthcare in Russia to be unsatisfactory. Wealthy citizens in Russia now choose other countries that provide much higher levels of medical services (Table 5), in particular, Israel - 45\% of all destination choices, and Germany - $20 \%$ of all destination choices (Table 6). These two countries have become so popular as medical tourism destinations for cultural and geographical reasons at the same time: relative proximity means quick travel, either by air, or by land, while presence of large Russian-speaking diasporas in both countries assume minimal language barriers for the incoming patients.

The most popular among the Russian medical tourists today are the medical services that require the most advanced equipment and technologies used for diagnostics, treatment and comfortable long-term medical rehabilitation (cardiology, cardiac surgery, transplantology, eye surgery, oncology, orthopedics, plastic surgery, neurosurgery) (Table 4).

Also, the Russians tend to prefer treatment with the use of various natural resources: thermal waters (63\%), mineral waters $(61 \%)$ and medicinal mud (46\%); general therapy (35\%), cosmetic procedures (32\%), wraps (26\%) and inhalations (18\%) being the most popular (Daykhes et al., 2020). Despite the factor of geographical distance (especially from the 
largest Russian cities with their huge tourist demand), Thailand has already offered some solid advantages as a medical tourism destination for Russian-speaking tourists: Russian-speaking diaspora residing in Thailand for years, regular transportation between Thailand and major Russian cities, absence of visa formalities, etc.

Table 5. Major reasons behind the popularity of outbound medical tourism in Russia (Medical Tourism - Russian Tourist Profile, 2018)

\begin{tabular}{|l|c|}
\hline \multicolumn{1}{|c|}{ Major reasons } & $\%$ \\
\hline The cost of treatment & 35 \\
\hline Range of services & 32 \\
\hline Distance and location convenience & 12 \\
\hline Recommendations of friends & 12 \\
\hline Doctors recommendations & 8 \\
\hline Advertising & 1 \\
\hline
\end{tabular}

Table 6. Major destinations in Russian medical tourism (Medical Tourism - Russian Tourist Profile, 2018)

\begin{tabular}{|l|c|}
\hline \multicolumn{1}{|c|}{ Major destinations } & $\%$ \\
\hline European countries & 39,8 \\
\hline Asian countries & 18,3 \\
\hline Middle East & 22,2 \\
\hline CIS countries & 12,9 \\
\hline Other countries & 6,8 \\
\hline
\end{tabular}

Table 7. Medical services in Thailand popular among Russian Tourists (as of 2017 and 2020, compiled by the author)

\begin{tabular}{|l|c|c|}
\hline \multicolumn{1}{|c|}{ Medical services } & 2017 & 2020 \\
$\%$ & $\%$ \\
\hline Regular health check & 29 & 22 \\
\hline Manual therapy & 21 & 17 \\
\hline Recovery after cosmetic surgery & 14 & 11 \\
\hline Dental services & 12 & 3 \\
\hline Cosmetic services (operable) & 9 & 16 \\
\hline Body adjustment services & 8 & 14 \\
\hline $\begin{array}{l}\text { Childbirth (including prenatal and } \\
\text { postnatal treatment) }\end{array}$ & 3 & 11 \\
\hline Detox, body cleansing, retreat tours, etc. & - & 7 \\
\hline
\end{tabular}

Table 8. Key findings from the survey (compiled by the author)

\begin{tabular}{|c|c|c|}
\hline & Finding & Author's comment \\
\hline $62 \%$ & $\begin{array}{l}\text { know about the medical tourism } \\
\text { potential of Thailand }\end{array}$ & \multirow{3}{*}{$\begin{array}{l}\text { The initial attitude of Russian } \\
\text { tourists (even when they do not } \\
\text { have personal experience) to the } \\
\text { opportunity of medical tourism } \\
\text { in Thailand is positive. } \\
\text { Reputation of Thailand as a } \\
\text { medical services destination is } \\
\text { also positive. }\end{array}$} \\
\hline $41 \%$ & $\begin{array}{l}\text { have positive attitude towards the } \\
\text { medical treatment in Thailand }\end{array}$ & \\
\hline $27 \%$ & $\begin{array}{l}\text { have personal experience of } \\
\text { treatment or medical care in } \\
\text { Thailand }\end{array}$ & \\
\hline $28 \%$ & $\begin{array}{l}\text { have already received some } \\
\text { information about the state of } \\
\text { medical tourism in Thailand from } \\
\text { reports and expert interviews }\end{array}$ & \multirow{2}{*}{$\begin{array}{l}\text { Traditionally, tours from } \\
\text { Russia to Thailand belong to } \\
\text { the mass market sector. To } \\
\text { some extent, this limits the } \\
\text { opportunities to purchase } \\
\text { more individualized medical } \\
\text { tours. }\end{array}$} \\
\hline $54 \%$ & $\begin{array}{l}\text { noted that have never got any } \\
\text { information on the opportunities of } \\
\text { medical tours to Thailand }\end{array}$ & \\
\hline $36 \%$ & $\begin{array}{l}\text { mentioned the following } \\
\text { advantages of having medical } \\
\text { treatment in Thailand: quality of } \\
\text { care; level of servicing in medical } \\
\text { institutions; comfort level during } \\
\text { rehabilitation. }\end{array}$ & \multirow{2}{*}{$\begin{array}{l}\text { Still, Thailand is not seen as } \\
\text { a destination for serious } \\
\text { medical treatment and } \\
\text { surgeries. The country is } \\
\text { primarily perceived as a } \\
\text { place for comfortable } \\
\text { rehabilitation, regular health } \\
\text { checkups, physical therapy, } \\
\text { etc. }\end{array}$} \\
\hline $25 \%$ & $\begin{array}{l}\text { noted the following advantage of } \\
\text { having medical treatment in } \\
\text { Thailand: technological quality of } \\
\text { the equipment used during } \\
\text { surgeries, treatments and diagnostics }\end{array}$ & \\
\hline $18 \%$ & $\begin{array}{l}\text { noted that the cost of medical } \\
\text { services in Thailand is too high } \\
\text { and/or that Thai medical services } \\
\text { are overpriced }\end{array}$ & \multirow{2}{*}{$\begin{array}{l}\text { Obviously, medical treatment in } \\
\text { Thailand is chosen primarily } \\
\text { by the representatives of the } \\
\text { Russia's middle class, and for } \\
\text { this social group, the price } \\
\text { factor is of primary importance }\end{array}$} \\
\hline $41 \%$ & $\begin{array}{l}\text { that Thai medical services are } \\
\text { sive, however, not overpriced }\end{array}$ & \\
\hline
\end{tabular}

Data collection has been carried out by means of a survey carried out on two large groups of people - Russians now living in Thailand (namely, in Bangkok and Pattaya), and secondly, Russians permanently living in Russia itself.

The study was conducted in January, 2020, that is, just before the start of the global restrictions on international travels associated with the coronavirus pandemic that have been seriously affecting the tourism sector later.

The total number of the respondents was 482: of them, 274 people were from Russia (all international travelers, all older than 18 and able to make their own, independent decisions about medical treatments, their own need for a medical treatment and their ability to travel). Data Collection Procedures: locations for the survey - hotels of different categories in various parts of the city. To meet the objectives of our study we have primarily focused on the hotels of high category and also on tourist information centers and medical tourism exhibitions (in Moscow, Yekaterinburg, and Rostov-on-Don).

\section{RESULTS AND DISCUSSION}

Key data and results from our 2020 survey are presented in Table 8. Previously, the author of this article has already carried out similar research into the perceptions and attitudes to medical tourism in Russia (Ushakov et al., 2019), and there are some time changes and differences that we would like to bring to the readers' attention:

- the number of respondents with the awareness about Thailand's potential in medical tourism grew from $56 \%$ up to $62 \%$. Similar trend has been demonstrated by the number of the Russians with personal experience in using medical services in Thailand (grew from $15 \%$ to $27 \%$ );

- some growth is observed in the share of the respondents who received expert information about the medical tours to Thailand. This indirectly confirms that Thailand's efforts on promotion of such tours in Russia have been relatively efficient. Yet, the share of those with no access to such expert information and those not aware of medical tours to Thailand as such is still very high;

- a decrease is observed in the share of the respondents appreciating the quality of rehabilitation and comfort in Thailand (36\% as compared to $42 \%$ previously). At the same time, the share of those convinced in technological advancement of the medical services in Thailand somewhat grew;

- analysis of the respondents' demographics (income, travel experience, level of monthly spending, readiness to spend a certain amount on medical services) demonstrates that the share of the middle class among those inclined to buy medical tours to Thailand is still very significant. At the same time, European countries, USA and Israel remain to be popular as high-income destinations in medical tourism. 
- the share of those convinced that medical services in Russia are worse than those in Thailand went down and reached $9 \%$. At the same time, a slight increase (from $36 \%$ to $38 \%$ ) is observed in the share of those aware of the possible negative consequences from the medical treatment in Thailand. Considering that the overall number of those with personal experience of medical tourism in Thailand grew not that significantly, this can be interpreted as a rather bad sign.

Table 3 below overviews the most popular types of medical services (those already used by Russian tourists in Thailand or those that the Russian tourists would like to try).

In our opinion, significant changes in the statistics above have been predetermined by the following trends:

- first of all, detox and retreat programmes have gained much popularity in Russia recently. In case of Thailand, such tours could be also easily combined with vacationing in the mountains and/or on the seaside, doing sports outdoors, yoga practice and meditation and even educational tours. Also, prenatal and postnatal care in Thailand is usually organized in very comfortable conditions (which always include a top-quality hotel), while in Russia such services are either not provided (in some regions) as such, or are much more expensive than in Thailand;

- secondly, with the internationally growing popularity of plastic surgery and other body/facial improvements, the leadership of Thailand has been gradually acknowledged in many countries globally. Thus, today Thai medical services are seen as much more trustworthy than similar procedures carried out in Russia (even though in Russia they can be much cheaper). Besides, some of the medicines and medical procedures (primarily those of purely Asian production) are now being actively promoted by Thailand's clinics while they are still banned in Russia (this includes separate types of fillers, bioadditives, low-temperature procedures, treatments methods based on the use of magnetic and electric waves, hormone injections, stem cells injections and so on) (Lunt and Carrera, 2010);

- thirdly, some of the services demonstrate decreasing popularity, primarily due to the growing spread of similar services in Russia itself. This concerns dentist services (today in Russia such services are already offering an adequate level of both technology and comfort while being somewhat cheaper than in Thailand). Interestingly, this also concerns such typically Thai services as manual therapy and spa (those become easily accessible all over the world and often cost less at home). In other words, in some cases, medical tours to Thailand have become not feasible, from the standpoints of both time and cost (Carrera and Bridges, 2006). Moreover, many of our respondents do not really see spa and manual therapy as part of medical services, for them, these are usual leisure activities.

On the one hand, the described changes emphasize that many Russians perceive treatment in Thailand only as one more service that accompanies the rest of their tour. This fact opens up some opportunities to optimize the tourist offer at the Russian market. For example, short-term tours for the whole family, apart from the standard beach element, should also offer additional activities - to correct posture, treatment of platypodia, procedures normalizing blood pressure or skin condition, etc. On the other hand, it becomes obvious that the Russians today are more interested in purchasing more high-tech, "fashionable", trendy medical services that are associated with the highest qualifications of medical specialists in Thai clinics, most advanced equipment and profile treatment with high added value overall. Problems faced by Russian tourists serviced

Table 9. Major problems faced by Russian tourists when using tourist medical services in Thailand (as of 2017 and 2020, compiled by the author)

\begin{tabular}{|l|c|c|}
\hline \multicolumn{1}{|c|}{ Major problems } & $\begin{array}{c}2017, \\
\text { in \% }\end{array}$ & $\begin{array}{c}2020, \\
\text { in \% }\end{array}$ \\
\hline language difficulties (in documents) & 36 & 35 \\
\hline language barrier (in personal communication) & 21 & 9 \\
\hline high prices & 19 & 26 \\
\hline difficulties with making a choice & 16 & 15 \\
\hline difficulties with further use of Thai documents in Russia & 15 & 14 \\
\hline turnover of doctors in Thailand & 9 & 8 \\
\hline too narrow specialization of doctors & 6 & 8 \\
\hline $\begin{array}{l}\text { lack of trust; doubts about professional qualities of } \\
\text { doctors and consumer rights protection }\end{array}$ & 2 & 13 \\
\hline $\begin{array}{l}\text { spread of negative information about medical treatment } \\
\text { in Thailand and low quality of Thai medical services }\end{array}$ & 1 & 7 \\
\hline
\end{tabular}
Russian tourists in Thailand are forced to sign some documents that basically waive all the responsibility of Thai doctors and other medical staff) (Table 9). Lack of a Russian version in clinics' documentation also contributes to the problems with reputation and image. At the same time, we can also note some positive shifts.

The Russians today have much less problems and fears when it comes to communication in Thailand, for example. On the other hand, the share of those who fear to purchase medical services in the Kingdom due to specificity of processes organization, niche expertise of doctors and high rates of their turnover in clinics remains unchanged.

\section{CONCLUSION}

The results of our 2020 survey concerning the potential of the Russian market to supply customers to Thailand's medical tourism market and also the prospects of Thai medical tourist product promotion on other Russian-speaking markets overall confirm that quality of medical infrastructure (equipment in wards, comfort of stay, quality of meals provided) as well as quality of servicing (nursing, care, opportunities of using in-clinic/hospital infrastructure) are gradually losing their rankings as the [previously] decisive factors behind choosing Thailand as a destination for medical tourism.

At the same time, quality of medical infrastructure in Russia itself is gradually improving (new private clinics emerge in many large cities, many Soviet-age spa retreat centers are being heavily modernized, brand new spas and retreats are being 
opened offering a wide variety of health programs with a range of durations and costs). Thus, for many Russian tourists their own country often becomes a medical tourist destination, primarily due to the cost factor. Therefore, promoting Thai medical tourist product as an alternative should not be based solely on a "nice package" of near-medical services, this simply is not rational any longer. Moreover, packaged health tours (covering traditional tourist services + detox, general health treatment, meditations, yoga, etc.) are actually relatively new for Thailand, this tourism direction is now being actively developed (with direct participation of Russian tourism businesses). While Russia as a country is well familiar with this type of business activity, the history of many Russian health resorts covers over 200 years, going back to the 19th century. Health resort infrastructure, in some state/shape or another, is actually present in every region of the Russian Federation (Tsymbal and Spa Consultant, 2014).

In other words, today Russia as a medical tourist destination is able to offer a wider range of locations and services under lower prices, while in Thailand the range of services is relatively limited and costs more than "back at home". For example, special retreat programs in some niche hotels of Phuket or Chiang Mai may cost at least 200 USD per person per day (see Detox and Wellness at the Sanctuary Thailand, 2021). Back in Russia, the same price tag is applicable to the most prestigious health resorts located in the outer Moscow or in the Caucasus. In our view and taking into account the current situation on the Russian tourist market, promotion of Thailand's medical tourism should be based on a flexible combination of the widest offering covering various high-tech services, medical and near-medical services and full rehabilitation. For example, rhinoplasty, lipoplasty or childbirth, heart-related surgeries, liver recovery programmes, etc. should be combined with servicing options of several clinics and further rehabilitation/accommodation in the hotels of various categories. Thus, tourists may individually adjust the "from-to" price range for each specific product/service in a package (for example, doctor's visit may be in some cases substituted by an online consultation). For many Russian tourists, one of the most unpleasant surprises while vacationing would be to have extra spending. Many of them would easily agree to pay extra 1000-2000 USD but while still purchasing a tour back in Moscow (or other city), while paying exactly the same amount being already on a Thai resort is perceived to be extremely inconvenient (Reshetnikov et al., 2019). Taking this purely psychological peculiarity, Thailand's medical tourism businesses should make sure the initial pricing offer is trustworthy enough and does not entail any sudden changes once the tourist travels to Thailand. At the same time, Russian tourists should have the ability to manage/adjust the total price for a tour (changing, for example, the hotel category, choosing a less known clinic, selecting between several categories of wards and so on). This would provide them with a convenient capacity to manage both their spending and their expectations.

These days we can obviously observe an internationally growing popularity of such medical tourist activities as detox programs, anti-aging tours, weight and eating behavior management, cosmetology for different age groups, mental health treatment (including yoga, meditations and anti-stress practices), post-surgery and post-Covid rehabilitation, and Russia is not staying outside of these trends. Orienting on Russian-speaking tourists, Thailand needs to support the new type of hospitality, with the emphasis on a stronger niche specialty of hotels. Such hotels should not be seen as "yet another spa hotel" (as we've mentioned earlier in Russia spa services are not perceived as a serious type of treatment but rather as a nice bonus to a vacation/tour). Of course, all of such changes would require not only extra efforts on the side of tourism businesses and hotels, but also government support. The government of Thailand needs to develop and introduce new rules of tourism services certification. The list of regions specializing in tourism services of this type may be also revised. Investment stimulation should cover the following aspects of Thai medical tourism development: the most expensive and technologically advanced medical equipment; unique services provided by medical staff; licensing and certification procedures (based on: Alsharif et al., 2010).

From the very beginning investors should be ready to know that spending in such hotels and other facilities would be much higher than investment in a regular, standard hotel. Investors and business owners also need to keep in mind that under higher spending and extra operational costs the profitability of such health resorts (considering their orientation on the middle class of Russian-speaking travelers the price range needs to be limited to 100 USD per person a day maximum) would be relatively low. This automatically means that the Government would need to provide extra preferences (preferential crediting programs in the first place) in order to support the long-term prospects of these hotels of a new type. Besides, such hotels can be situated in places away from popular tourist locations. This would help with reducing spending on personnel, food products and medical services as well (Heung et al., 2010). Finally, such hotels should be getting financial assistance from the Ministry of Healthcare (namely, such assistance should cover part of the medical equipment costs, personnel training and other important expenses). Interestingly, popularity of this direction in the hospitality sector can be strengthened through post-Covid reformatting: reeducating the personnel fired from other hotels due to bankruptcy, reorienting the unprofitable standard hotels taking into account the latest trends in the changing internal and international demand for medical services in tourism. The 2020-2021 pandemic as such has seriously increased the interest in comfortable, socially isolated leisure with direct access to medical staff, and this interest would, most probably, be a long-term one. We can also expect that once the healthcare situation is normalized, in the world overall and in Thailand in particular, many hotels and resorts (especially those of higher categories) would be forced to change their usual concept and strategy.

First and foremost, approaches to hotels' capacity in terms of room numbers will be certainly revised. At the same time, reducing the total number of rooms, hotels need to make sure they are providing much more extra services for the now smaller number of hotel guests (as this would keep income on the previous level). Such extra services provided in a hotel should definitely include medical ones. Since many elite-class hotels are anyway located near famous medical centers and hospitals, medical staff may work part-time (or an hourly basis) in these hotels. Besides, since hotels would be forced to reduce their capacity, part of the already available facilities can be turned into medical departments and/or offices (one floor or even a separate building in case of larger resorts). We need to mention here that these processes are already taking place, actually. Take Ban Souchada Resort in Saraburi, for example (see: https://www.souchadaresort.com/blank-ymnws ). Several years ago it used to be a standard golf center, and in the last two years it gradually turned into a small health resort, now offering 1-2-3- 
day health treatment tours with detox, fitness and anti-stress components. Initially, these services were oriented primarily on the wives of golf players coming from Bangkok but now the resort has seriously widened its target audience.

Similar programs and tours are offered in the well-known Chiva-Som in Huahin. Overall, in the last 2-3 years around 10 socalled retreat hotels have emerged (or been reformatted) in the vicinity of Bangkok. Since thermal waters and hydrotherapy overall are highly popular among Russian and Russian-speaking tourists, Thailand should pay more attention (on both business and governmental levels) to the opportunities of promoting own thermal waters among current and potential tourists. Larger part of the Kingdom (mainly Western and Northern regions) is located in the highly seismic, mountainous zone which has a lot of natural thermal springs. Most of them are located in Chiang Mai, Chaing Rai, Kanchanaburi, Kamphaeng Phet and Rayong provinces of Thailand. In many cases healing properties and potential of these springs are not yet studied at all. Thus, relevant ministries should organize (by own means or inviting foreign experts) the chemical analysis of the thermal water properties and also estimate its volumes. On the basis of this data, new resort zones may be formed in the country, being oriented on thermal treatment and other elements of hydrotherapy. Obviously, this whole process is quite expensive and a long-term one, however, Thailand really has the potential to create a brand new tourism subsector from scratch, and this subsector would be on the borderline between tourism and healthcare. Besides, those thermal springs that are already developed and known in Thailand are already overcrowded by local, Thai tourists on a nearly daily basis. Our final recommendation on promotion of Thai medical tourist product on the Russian market concerns arranging more active cooperation between Thailand's authorities and the Russian Association of Resort \& Spa Treatment since the latter public body has the capacity to promote not only Russian resorts but is also engaged in state-level systematization of the related data on the world tourism resources. To simplify the process of choosing the right place for diagnostics and treatment, we consider it logical to propose a national system for assessing the achievements of hospitals and clinics in various areas of medical science and healthcare. Availability of such a national system would allow having real-time hospitals' rankings based on the number of patients admitted, treated and cured, patient reviews, compliance with international and national standards, and other parameters. This official rating can be determined every year or every two years, for example. Obviously, it should be made freely available, so that any tourist from any country of the world can make their well-grounded choice of a hospital/clinic operating the most relevant and useful information. Finally, there must be some sort of a system for adapting Thai medical documents and diagnostic standards to the standards and regulations in other countries. This would not actually require significant expenditures, and each hospital can implement such an interpretation system independently, after a series of consultations with Russian specialists, while such consultations can be relatively easily arranged in the format of a conference (offline or through teleconferencing).

\section{REFERENCES}

Aizura, A. (2019). Where Health and Beauty Meet: Femininity and Racialisation in Thai Cosmetic Surgery Clinics. Asian Studies Review, 33(3), 303-317. https://doi.org/ 10.1080/10357820903153707

Alsharif, M.J., Labonté, R., \& Zuxun, Lu. (2010). Patients beyond borders: A study of medical tourists in four countries. Global Social Policy, 10(3), 315-335. https://doi.org/10.1177/1468018110380003

Carrera, P., \& Bridges, J. (2006). Globalization and healthcare: understanding health and medical tourism. Expert Review of Pharmacoeconomics and Outcomes Research, 6 (4), 447-454. https://doi.org/10.1108/09526861111160580

Daykhes, A., Jakovljevic, M.,. Reshetnikov, V., \& Kozlov, V. (2020). Promises and Hurdles of Medical Tourism Development in the Russian Federation. Frontiers in Psychology, 23.06. https://doi.org/10.3389/fpsyg.2020.01380

Gupta, H.D. (2004). Medical tourism and public health. Peoples Democracy. 27(19), Access:11.03.2021. http://pd.cpim.org/2004/05092004_snd.htm

Heung, V.C.S., Kucukusta, D., \& Song, H. (2010). A Conceptual Model of Medical Tourism: Implications for Future Research. Journal of Travel \& Tourism Marketing, 27(3), 236-251. https://doi.org/10.1080/10548401003744677

Lunt, N., \& Carrera, P. (2010). Medical tourism: Assessing the evidence on treatment abroad. Maturitas, 66(1), 27-32. https://doi.org/10.1016/j.maturitas.2010.01.017

Reshetnikov, V., Arsentyev, E., Boljevic, S., \& Jakovljevic, M. (2019). Analysis of the financing of Russian healthcare over the past 100 years. International Journal of Environmental Research and Public Health, 6, 1848. https://doi.org/10.3390/ijerph16101848

Tsymbal, N., \& Spa Consultant. (2014). Overview of Wellness Tourism in Russia. Access: 02.03.2021. https://www.slideshare.net/ weldest/overview-of-wellness-tourism-in-russia-by-nina-tsymbal-2014

Turner, L. (2007). 'First World Health Care at Third World Prices': Globalization, Bioethics and Medical Tourism. BioSocieties, 2(3), 303-325. https://doi.org/10.1017/s1745855207005765

Ushakov. D., Yushkevych, O., Ovander, N., \& Vyhovskyi, V. (2019). The strategy of Thai medical services promotion at foreign markets and development of medical tourism. Geojournal of Tourism and Geosites, XII, 27(4),1429. https://doi.org/10.30892/gtg.27426-445

Vetitnev, A., \& Dzubina, A. (2018). Spaservices and sanatorium-resort complexes of Russia Tourism. An International Interdisciplinary Journal, 61(2), 187-200.

Wilson, A. (2020). Medical Tourism in Thailand. Asian Biotech, Chula press. https://doi.org/10.1515/9780822393207-006

*** Baan Soudchada Resort and spa (2021). Programs \& Packages, Access: 02.03.2021. https://www.souchadaresort.com/blank-ymnws

*** Detox \& Wellness at the Sanctuary Thailand (2021). Access: 13.06.2021. https://www.thesanctuarythailand.com/detox-packages-5-nights.html.

*** Medical Tourism - Russian Tourist Profile (2018). Access: 13.06.2021. https://canarymedicalkey.com/health-tourism/profilerussian-medical-tourism

*** National Strategy Committee (2017). National Strategy for 2018-2037. Summary, Access: 13.06.2021. http://nscr.nesdb.go.th/wpcontent/uploads/2019/10/National-Strategy-Eng-Final-25-OCT-2019.pdf

*** Thailand Medical News (2019). Thailand Medical Tourism Industry On A Downward Path. Access: 13.06.2021. https://www. thailandmedical.news/news/thailand-medical-tourism-industry-on-a-downward-path

***Top-10 Global Destinations of Medical Tourism (2019). Access: 13.06.2021. https://pharmaboardroom.com/facts/thailand-medicaltourism-snapshot

*** Tourism statistics for 15 Major Nationalities (2019). Access: 13.06.2021. www.thaiwebsites.com 